\title{
Towards a Globalization of Aging
}

\author{
JASON L. POWELL
}

Abstract. This article locates an understanding of comparative grounding of aging through the theory of globalization. It reviews the trends of aging in various countries across the continents and points out important policy issues facing nation states with decreasing sovereignty in the face of various challenges brought about by globalization. The need to reconsider theorizing aging by exploring and integrating theories of globalization is highlighted.

Keywords: Aging, Globalization, International Inquiry, Social Policy, Theory Building

Résumé. Cet article situe la compréhension du vieillissement comparative à travers la théorie de la mondialisation. Il examine les tendances du vieillissement dans différents pays à travers les continents et souligne d'importants enjeux stratégiques auxquels sont confrontés les Etats-nations avec la diminution de la souveraineté face à divers défis posés par la mondialisation. La nécessité de reconsidérer la théorisation du vieillissement en explorant et en intégrant les théories de la mondialisation est mis en evidence.

Mots clés: Le vieillissement, la mondialisation, l'enquête internationale; la politique sociale; la construction de la théorie

\section{INTRODUCTION}

lobalization is both a social practice subject and a theoretical tool. It does include increased human interconnectedness facilitated by new information technologies and huge volumes of trade, capital, people, cultures flowing across national borders, and an ever more integrated global economy (McDaniel and Zimmer 2013). Globalization can be experienced as structural forces impinging on daily lives, as the creation of new spaces and connectivity between locales and also as ideological resources (Phillipson 2013). On the other hand, between 2006 and 2030, the number of older people in less developed countries is projected to escalate by $140 \%$ as compared to an increase of $51 \%$ in more developed 
countries (McDaniel and Zimmer 2012). The forecast rise in the number of older people aged seventy five plus over the next twenty years will lead to an expansion of demand for health, housing accommodation and pensions for aging populations and is thus of crucial importance for governments, policy makers, planners, and researchers in all nation states. On a global level, the eighty five-and-over population is projected to increase $151 \%$ between 2005 and 2030, compared to a 104\% increase for the population age sixty five and over and a $21 \%$ increase for the population under age sixty five (Powell 2011).

In advanced capitalist or First World countries, declines in fertility that began in the early 1900s have resulted in current fertility levels below the population replacement rate of two live births per woman. Perhaps the most surprising demographic development of the past twenty years has been the pace of fertility decline in many less developed countries (McDaniel and Zimmer 2012). In 2006, for example, the total fertility rate was at or below the replacement rate in forty four less developed countries (Cook and Powell 2010). Most of the more developed nations have had decades to adjust to this change in age structure. For example, it took more than a century for France's population age sixty five and over to increase from $7 \%$ to $14 \%$ of the total population. In contrast, many less developed or Third World countries are experiencing rapid increases in the number and percentage of older people, often within a single generation. The same demographic aging process that unfolded over more than a century in France will occur in two decades in Brazil (McDaniel and Zimmer 2012). In response to this compression of aging, institutions must adapt quickly to accommodate a new age structure. Some less developed nations will be forced to confront issues, such as social support and the allocation of resources across generations, without the accompanying economic growth that characterized the experience of aging societies in the West. In other words, some countries "may grow old before they grow rich" (Cook and Powell 2010).

Globalization has also produced a distinctive stage in the social history of population aging, with a growing tension between nation statebased solutions (and anxieties) about growing old and those formulated by global institutions (Powell 2005). Globalization, defined here as the process whereby nation-states are influenced (and sometimes undermined) by trans-national actors (Powell 2005), has become an influential force in shaping responses to population aging. Growing old has, itself, become relocated within a trans-national context, with international organizations (such as the World Bank and International Monetary Fund) and cross-border migrations, creating new conditions and environments for older people. Globalization is characterized by the development of 
an increasingly integrated global economy with free trade, free flow of capital, and the tapping of cheaper foreign labor markets. A globalized world is integrated but not harmonious, a single place but diverse, a construct of consciousness but prone to multiplicity and fragmentation. In that context, it is highly pertinent that critical social science steps up to the challenge and rethinks how we "unmask" the implications of globalization and impact on understanding aging.

Globalization has become one of the central but contested concepts of contemporary social science (Ritzer 2004). The term has further entered everyday commentary and analysis and features in many political, cultural, and economic debates. The contemporary globalized world order originates in the international organizations and regulatory systems set up after World War II - including the United Nations, General Agreement on Tariffs and Trade (now the World Trade Organization), the International Monetary Fund, and the World Bank (Bauman 1998). However, the end of the Cold War was the prelude to the maturity of the concept of globalization. From 1989 to present, it is possible at least to imagine a "borderless" world (Ohmae 1990) in which people, goods, ideas, and images would flow with relative ease, and the major global division between East and West had gone. A world divided by competing ideologies of capitalism and state socialism has given way to a more uncertain world in which capitalism has become the dominant economic and social system, even for the communist-led People's Republic of China. Coinciding with these changes, a major impetus to globalization was the development and availability of digital communication technologies from the late-1980s with dramatic consequences for the way economic and personal behavior were conducted - this has transcended to mass communication from the Internet in the 1990s to mobile phones from 2000 onwards (McGrew 2007). The collapse of communism in Eastern Europe and the USSR, and its modernizing in China, plus growth of digital technologies further coincided with a global restructuring of the state, finance, production, and consumption associated with neo-liberalism. The consequence is that globalization as a spatial process has facilitated the emergence of a new kind of global city based on highly specialized service economies that serve specific, particularized functions in the global economic system at the expense of former logics of organization tied to manufacturing-based economies. To enable global markets to function effectively, they need to be underpinned by local managerial work that is concentrated in cities. Further, privatization and deregulation during the 1980s and 1990s shifted various governance functions to the corporate world, again centralizing these activities in urban spaces. In post-industrial cities there is a concentration of command functions 
that serve as production sites for finance and the other leading industries and provide marketplaces where firms and governments can buy financial instruments and services. Global cities become strategic sites for the acceleration of capital and information flows, and at the same time spaces of increasing socioeconomic polarization.

One effect of this process has been that such cities have gained in importance and power relative to nation-states. There have emerged new "corridors" and zones around nodal cities with increasingly relative independence from surrounding areas. Globalization simultaneously brings home and exports the processes of privatization, competition, rationalization, and deregulation as well as the transformation of all sectors of society through technology and the flexibilization and deregulation of employment. As a process, debate centers on the uses of globalization as the rationale and means by which corporate capital may transnationally pursue new low wage strategies and weaken the power of aging populations.

Therefore, aging can no longer just be viewed as a "national" problem but one that affects trans-national agencies and communities. Local or national interpretations of ageing had some meaning in a world where states were in control of their own destiny (Estes, Biggs and Phillipson 2003). The crisis affecting each of these areas, largely set in motion by different aspects of globalization, is now posing acute challenges for understanding "global aging" in the twenty-first century.

Since 2000, the life expectancy of people born in North America has increased by approximately twenty five years and the proportion of persons sixty five years or older has increased from $4 \%$ to over $13 \%$ (Estes and Associates 2001). By the year 2030, one in five individuals in the U.S. is expected to be sixty five years or older and people age eighty five and older make up the fastest growing segment of the population. In 2000, there were 34 million people aged sixty five or older in the United States that represented $12.4 \%$ of the overall population. By 2030, there will be about 72.1 million older persons, or $19 \%$ of the population, more than twice their number in 2000 . The older population - persons sixty five years or older - numbered 39.6 million in 2009, representing $12.9 \%$ of the U.S. population (http://www.aoa.gov/aoaroot/aging_statistics/index.aspx retrieved on September 12, 2012).

The percentage of oldest old will vary considerably from country to country. In the United States, for example, the oldest old accounted for $14 \%$ of all older people in 2005 . By 2030 , this percentage is unlikely to change because the aging baby boom generation will continue to enter the ranks of the sixty five-and-over population (Bengston and Lowenstein 2004). 
The family structure will be different, too, not least because people currently divorced constitute a small proportion of older populations. This will soon change in many countries as younger populations with higher rates of divorce and separation age. In the United States, for example, $9 \%$ of the sixty five-and-over population is divorced or separated compared to $17 \%$ of people age fifty five to sixty four and 18 percent of people age forty five to fifty four (Manton and Gu 2001). This trend has gender-specific implications: in all probability nonmarried women are less likely than nonmarried men to have accumulated assets and pension wealth for use in older age, while older men are less likely to form and maintain supportive social networks.

Shoring up public pensions is hardly the only avenue nations in North and South America are exploring. In many countries, privately managed savings accounts have been strongly advocated (Estes and Associates 2001). Two decades ago, nearly every South American nation had pay-as-you-go systems similar to the US Social Security system. Some granted civil servants, retiring in their fifties, full salaries for life. Widening budget deficits changed that. In 1981, Chile replaced its public system with retirement accounts funded by worker contributions and managed by private firms. The World Bank encouraged eleven other Latin nations to introduce similar features. For example, in Chile the government addressed its fiscal budget deficit by mobilizing $\$ 49$ billion of pension-fund assets that make it easier for companies and corporations to fund investments in the local currency with bond offerings, and most workers have some retirement benefits from this (OECD 2007). At the same time, the downside has been those people who cannot afford a private pension, left to a low state pension which has intensified poverty (Powell 2011). This is an enduring feature of all nation states in America. For the future, there is no safety guarantee that private pension schemes are protected and pay out for people who invest their savings in such provision. In a de-regulated U.S. pension system, the issue of corporate crime has highlighted the continuing problem of private pension provision. In one example, this was seen clearly with the energy corporation of Enron's embezzlement of billions of dollars of employees private pension schemes (Powell 2011). This debate amounts to a significant global discourse about pension provision and retirement ages, but one which has largely excluded perspectives that might suggest an enlarged role for the state, and those which might question the stability and cost effectiveness of private schemes. The International Labor Organization (ILO) concluded that investing in financial markets is an uncertain and volatile business: that under present pension plans people may save up to 30 per cent more than they need, which would reduce their spending 
during their working life; or they may save 30 per cent too little - which would severely cut their spending in retirement (Phillipson 1998; Estes, Biggs and Phillipson 2003).

Increasingly, the social infrastructure of welfare states is being targeted as a major area of opportunity for global investors. The World Bank has expressed the belief that the public sector is less efficient in managing new infrastructure activities and that the time has come for private actors to provide what were once assumed to be public services. This view has been strongly endorsed by a variety of multinational companies, especially in their work with the World Trade Organization (WTO). The WTO enforces more than twenty separate international agreements, using international trade tribunals that adjudicate disputes. Such agreements include the General Agreement on Trade in Services (GATS), the first multilateral legally enforceable agreement covering banking, insurance, financial services and related areas (Estes, Biggs and Phillipson 2003).

Asia has the fastest increase in the aging population in the world. Kim and Lee (2007) claim the growing elderly population is beginning to exert pressure on the East Asian countries' economies. Three decades ago, major industrialized countries have begun to grapple with similar problems. With increasing drop in fertility rates, more East Asian economies such as Japan, Hong Kong, South Korea, Singapore and Taiwan are expected to turn into "super-aging societies" by 2025 (Kim and Lee 2007). However, the magnitude of the future impact depends on the (in) ability of individual economies to resolve the demographic change problems through increased privatization, pension reforms, a migration to more productive countries, and extension of retirement age. Like Western countries, Asia will ultimately have to tackle issues related to pension reform and the provision of long-term health care services (Cook and Powell 2010).

For Japan, the basic statistical reality of its aging demographic profile is escalating. Already, seventeen of every 100 of its people are over sixty five, and this ratio will near thirty in fifteen years. From 2005 to 2012, Japan's workforce was estimated to shrink by around 1\% each year - a pace that would accelerate after the period. Economists fear that, besides blowing an even bigger hole in Japan's underfunded pension system (Chen and Powell 2011), and the decline of workers and young families will make it harder for Japan to generate new wealth.

The future challenge of providing for the elderly is especially urgent in the world's two most populous nations - China and India. Only $11 \%$ of Indians have pensions, and they tend to be civil servants and the affluent. With a young population and relatively big families, many of the elderly 
population still count on their children for support. This is not even the case in China. By 2030, there will be only two working-age Chinese people to support every retiree. Yet only $20 \%$ of Chinese workers have government- or company-funded pensions or medical coverage (Cook and Powell 2010). However, as a counterbalance to such a gloomy perspective, "Chindia" (China and India taken together) is currently accumulating vast wealth as a result of globalization, wealth that could potentially be redirected for the support of their elderly populations.

The population structure of Western European countries has changed since the turn of the $20^{\text {th }}$ century. Whereas in 1901 , just over $6 \%$ of the population were at or over current pension age (sixty five in the UK for men and women), this figure rose steadily to reach 18\% in 2001 (Powell $2005)$. At the same time, the population of younger people under age sixteen fell from $35 \%$ to $20 \%$. As European countries reach a relatively high level of population aging, the proportion of workers tends to decline. European countries, including France, Germany, Greece, Italy, Russia, and the Ukraine already have seen an absolute decline in the size of their workforce. And in countries where tax increases are needed to pay for transfers to growing older populations, the tax burden may discourage future workforce participation. The impact on a nation state's gross domestic product will depend on increases in labour productivity and that state's ability to substitute capital for labour. Less developed countries can shift their economies from labour-intensive to capital-intensive sectors as population aging advances. Options for more European nation states may be more constrained. The "rolling back" of pensions promises is just one symptom of a shift in European history: the "greying of the baby-boom generation" (Phillipson 1998). The percentage of sixty-yearolds and older are growing $1.9 \%$ a year. This is $60 \%$ faster than that of the overall global population. In 1950, there were twelve people aged fifteen to sixty four to support each one of retirement age. Currently, the global average is nine. It will be only four-to-one by 2050 (Powell 2005). By then, numbers of older people will outnumber children for the first time. Some economists fear this will lead to bankrupt pensions and lower living standards. It is interesting that in Germany this fear is becoming a battleground for political electioneering. For example, Germany has the third oldest population in the world, which presents both critical questions on public finances to provide pensions and healthcare and an opportunity for innovations in the marketplace.

The trend has drawn further attention across Europe, where the working-age population was predicted to decline by $0.6 \%$ in 2010 . By 2025 the number of people aged fifteen to sixty four is projected to dwindle by $10.4 \%$ in Spain, $10.7 \%$ in Germany and $14.8 \%$ in Italy. But aging is just 
as dramatic in such emerging markets as China - which is expected to have 265 million sixty five-year-olds by 2020 - and Russia and Ukraine (Cook and Powell 2007).

In Great Britain, the percentage of people of working age, that is sixteen - sixty four, will drop from 64\% in 1994 to 58\% in 2031 (Powell 2011). As the number of workers per pensioner decreases, there will be pressure on pension provision. This is evident now; in such areas of pensions and long term care, the retreat of the state made evident in the erosion of State Earnings Related Pay is forcing people to devise their own strategies for economic survival in old age (Phillipson 1998). In the British context that also impinges on global societies in general, private pensions are slowly being introduced in order to prevent the "burden" of an aging population. These are ways in which the State continues to rely on apocalyptic projections such as "demographic time bomb" about aging populations in order to justify cuts in public expenditure (Powell 2005). In reality, the population of Great Britain, like that of other European countries, is ageing rapidly. There are only enough young people to fill one in three of the new and replacement jobs that will need to be taken up over the next decade. Older people take much of the responsibility for our social and civic life and for the care of children, the sick, and the very old in the community. Yet the gap between wealth and poverty, choice and the absence of choice for older people is stark and growing wider (Phillipson 1998). The UK government is at the time of seeking to promote a debate over what they envisage as a multi-billion pound deficit that will be found in care for the elderly in future.

Economic security, health and disability, and living conditions in old age are policy concerns throughout the world, but the nature of the problem differs considerably from continent to continent and between and within countries - especially within Africa.

In Africa, older people make up a relatively small fraction of the total population, and traditionally their main source of support has been the household and family, supplemented in many cases by other informal mechanisms, such as kinship networks and mutual aid societies. In 2005, Nigeria ranked among the top thirty countries in the world on the basis of the size of its population age sixty and over. Nigeria had the largest older population in sub-Saharan Africa, with over 6 million people age sixty and over; South Africa had just over 3.4 million. Congo and South Africa are projected to have nearly 5 million older people in 2030. Burkina Faso, Cameroon, Cote d'Ivoire, Madagascar, Mozambique, Niger, Senegal, and Uganda are all projected to have their older populations grow to over one million people by 2030 (Building Blocks 2004). African economies are still heavily dependent on subsistence agriculture, 
and average income per capita is now lower than it was at the end of the 1960s. Consequently, the region contains a growing share of the world's poor. In addition, reductions in fertility and child mortality have meant that, despite the huge impact of the HIV/AIDS epidemic across much of the region, both the absolute size and the proportion of the population age sixty and over have grown and will continue to grow over the next thirty years (Estes, Biggs and Phillipson 2003).

For the most part of Africa, as in other traditional societies such as those in India or China, older people have traditionally been viewed in a positive light, as repositories of knowledge and wisdom. And while African families are generally still intact, development and modernization are closely connected with social and economic changes that can weaken traditional social values and networks that provide care and support in later life. Africa has long carried a high burden of disease, including malaria and tuberculosis; today it is home to more than $60 \%$ of all people living with HIV - some 25.8 million in 2005 . The vast majority of those affected are still in their prime wage-earning years, at an age when, normally, they would be expected to be the main wage earners and principal sources of financial and material support for older people and children in their families. Many older people have had to deal with the loss of their own support while absorbing the additional responsibilities of caring for their orphaned grandchildren. Increasingly, then, it appears that African societies are being asked to cope with population aging with neither a comprehensive formal social security system nor a well-functioning traditional care system in place (Building Blocks 2004).

Epstein (2001) notes that between 1950 and the late 1970s, life expectancy increased by at least ten per cent in every developing country in the world, or on average by about fifteen years. However, at the beginning of the twenty-first century, life expectancy remains below fifty in more than ten developing countries, and since 1970 has actually fallen, or has barely risen in a number of African countries (Phillipson 1998). The AIDS epidemic is certainly a major factor here, but development loans requiring the privatization of health care have also had an impact. Epstein (2001) reports, for example, that by the mid-1990s the African continent was transferring four times more in debt repayment than it spent on health or education. More generally, Help Age International $(2000,8)$ argues that:

Older people's poverty is still not a core concern in the social, economic and ethical debates of our time. Their right to development is routinely denied, with ageing seen as a minority interest or case for special pleading. Poverty and social exclusion remain the main stumbling blocks to the realization of the human rights of older people worldwide. 
The globalization of aging will have dramatic effects on local, regional, and global economies. Most significantly, financial expenditures, labour supply, and total savings will be affected. Changes in the age structures of societies also affect total levels of labour force participation in society, because the likelihood that an individual will be in the labour force varies systematically by age. Concurrently, global population aging is projected to lead to lower proportions of the population in the labour force in highly industrialized nations, threatening both productivity and the ability to support an aging population. This critical questioning of the modernist basis to society is a challenging one to social theory. In a sense the traditional formulation of "society" is being challenged from global forces that impinge. Indeed, in a networked world, everyday life is becoming detached from the protective nation-state seen to be at the core of occidental modernity. A major dimension of inequities impinges on debates on issues such as climate change, power of multinational corporations, and third-world countries of debt repayment. The phenomenon of globalization has transformed debates within social theory to the extent that it has reordered concepts typically used by social theorists across micro-macro continuum (Bauman 1998). Ideas associated with the notion of modernity, the state, gender, class relations, aging, and ethnicity have retained their importance but their collective and individualized meaning is different and fragmented in the context of the influence of global actors and institutions (Powell 2006).

A contentious point is that accepting the importance of globalization also strengthens the case for rethinking social theory through reassertion of macro analysis. Given the explanatory role of social theory, globalization is setting major new challenges in terms of interaction between individuals, communities, and nation states and the global structure within which these are constructed, contested and nested. Analyzing the interpretation of daily life may be more appropriately assessed in the contexts of networks and flows characteristic of global society, these producing a loosening in those attachments which have traditionally embedded people to locative settings: for Marxists in social class and for Feminists in gendered configurations. With globalization, these attachments are maintained but recontextualized and reembedded with the influence of transnational communities, corporations and international governmental organizations producing new agendas and challenges for how we understand "modern society" (Turner 2006). Further, the nature of "citizenship" and "rights" so heavily influenced by Enlightenment philosophy are both heavily contested under the lead of the complex and commanding influences of powerful non-democratic intergovernmental structures such as the World Bank and International Monetary Fund (IMF), private multinational corporations 
such as banks and western states that are under new pressures associated with accelerating aging and migration. This contrasts sharply with the Enlightenment period which saw rights arguably independently defined and negotiated through various manifestations of British, European and American nation-building and sovereign state-based power.

It may also be suggested that democratic rights have become more fragmented as well as individualized. What has changed is the duty and necessity to cope with these risks that are being increasingly transferred to families (Bauman 2000). The new social construction of everyday life may be defined as a global problem and issue but the social reconstruction of how experience of globalization is being cast as a personal rather than a collective responsibility. This development also implies an important role for social theory in interconnecting macro and micro perspectives with new approaches in order to understand how global processes contribute to the reshaping of the institutions in which the experiences of social groups are embedded.

A further task must be to construct new social theories about the nature of individualization in light of more fluid borders surrounding nationstates. Important questions concern whether and how people, socially differentiated, are facilitated or constrained by the spread of mobile communities along with more varied forms of belonging and citizenship. Social theory will be profoundly influenced by the "development of a common consciousness of human society on a world scale and an increased awareness of the totality of human social relations as the largest constitutive framework of all relations" (Shaw 2002, 12).

A further issue concerns the extent to which social theory may challenge the dominant institutions that reproduce and perpetuate social divisions in society. Applications of the policy sciences take for granted existing systems of capitalism as scholars work largely within "definitions of the situation" that are framed by classical economic theories, assumptions and models of cost-effectiveness and individual level outcomes. The end result is that only a limited array of potentially viable policy options assuring the serious consideration of only incremental changes that will do little to alter the underlying structural economic problems facing older people.

\section{REFERENCES}

Bengston, V. L. and A. Lowenstein, eds. 2004. Global Aging and Challenges to Families. New York: De Gruyter.

Building Blocks. 2004. Africa-wide Briefing Notes - Supporting Older Carers. HIV AIDS Alliance and HelpAge International. 
Chen, S. and J. Powell, eds. 2012. Aging in China: Implications to Social Policy of a Changing Economic State. New York, NY: Springer.

Cook, I.G. and J.L. Powell, eds. 2007. New Perspectives on China and Aging. New York: Nova Science.

Du, P. and P. Tu. 2000. Population ageing and old age security. Pp. 77-90 in $\mathrm{X}$. Peng and Z. Guo, eds., The Changing Population of China. Oxford: Blackwell.

Epstein, H. 2001. Time of indifference. New York Review of Books. April 12, pp. 33-38.

Estes, C. and Associates. 2001. Social Policy and Aging. Thousand Oaks, CA: Sage.

Estes, C., S. Biggs, and C. Phillipson. 2003. Social Theory, Social Policy and Ageing. Milton Keynes: Open University Press.

Federal Reserve Bank of Kansas City. 2004. Global Demographic Change: Economic Impacts and Policy Challenges. Symposium proceedings, August 26-28, 2004. http://www.kc.frb.org/Publicat/sympos/2004/sym04prg. htm.

Gavrilov, L. and N. Gavrilova. 1991. The Biology of Life Span: A Quantitative Approach. New York: Harwood Academic Publisher.

Giddens, A. 1993. Sociology. Cambridge Polity Press.

Gilleard, C. and P. Higgs. 2001. Cultures of Aging. London: Prentice Hall.

Gruber, J. and D.A. Wise, eds. 1999. Social Security and Retirement around the World. Chicago, IL: University of Chicago Press. eds. 2004. Social Security Programs and Retirement around the World. Micro Estimation. Chicago, IL: University of Chicago Press.

Help Age International. 2000. The Mark of a Noble Society. London: HelpAge International.

Hermalin, A., ed. 2002. The Well-Being of the Elderly in Asia: A Four-Country Comparative Study. Ann Arbor, MI: University of Michigan Press.

Holtzman, R.A. 1997. A World Bank Perspective on Pension Reform. Paper prepared for the joint ILO-OECD Workshop on the Development and Reform of Pension Schemes, Paris, December.

International Monetary Fund. 2006. The economics of demographics. Finance and Development 43(3) http://www.imf.org/external/pubs/ft/ fandd/2006/09/.

Kim, S. and J-W. Lee. 2007. Demographic changes, saving and current account in East Asia. Asian Economic Papers 6(2).

Kinsella, K. and V.A. Velkoff. 2001). An Aging World: 2001. Washington, DC: National Institute on Aging and U.S. Census Bureau. 
Krug, E.G. 2002. World Report on Violence and Health. Geneva: World Health Organization.

Lopez, A.D., C.D. Mathers, M. Ezzati, D.T. Jamison, and C.J.L. Murray, eds. 2006. Global Burden of Disease and Risk Factors. Washington, DC: The World Bank Group.

Longino, C.F. 1994. Pressure from our aging population will broaden our understanding of medicine. Academic Medicine 72(10):841-847.

Manton, K.G. and X. Gu. 2001. Changes in the Prevalence of Chronic Disability in the United States Black and Nonblack Population above Age 65 from 1982 to 1999. Proceedings of the National Academy of Sciences, 98:6354-6359.

McDaniel and Zimmer, 2012. Global Aging: London: Ashgate

Organization for Economic Cooperation and Development (OECD) Directorate for Employment, Labour and Social Affairs. 2007. Disability Trends among Elderly People: Re-Assessing the Evidence in 12 OECD Countries (Interim Report). Paris, France: OECD.

Phillipson, C. 1998. Reconstructing Old Age. London: Sage.

Powell, J. (2005). Social Theory and Aging. New York: Rowman and Littelfield

Powell, J. (2006). Rethinking Social Theory and Later Life, NY: Nova Science

Powell, J. (2011). Aging, Theory and Globalization, NY: Nova Science

Powell, J.L. and I. Cook, eds. 2010. Aging in Asia. New York: Nova Science.

United Nations Department of Economic and Social Affairs. 2002. Population Division. World Population Aging 1950-2050. New York: United Nations.

Jason L. Powell Ph.D is Professor of Social Gerontology and Associate Dean of Faculty of Health and Life Sciences at Coventry University, UK. He has refereed articles published in top journals across the world: The China Journal of Social Work; The British Journal of Healthcare Management; The Scandinavian Journal of Caring Sciences; Asian Journal of Social Policy; and The Romanian Journal of Sociology. In the US, The Journal of Applied Gerontology had a special edition on his approach to ageing and professionalism. He was awarded the 'Highly Commended Article Award' in The International Journal of Sociology and Social Policy. He is Editor-in-Chief of US-based international journal, Illness, Crisis \& Loss. He has served on many international editorial boards: Human Affairs; International Journal of Social Welfare and Research on Aging. He is Series Editor of the International Aging Book Series for Springer in US.

jasonpw113@gmail.com. 
268 C Canadian Journal of Sociology/Cahiers Canadiens de sociologie 39(2) 2014 